\title{
HOW TO USE THIS BOOK
}

BIOGRAPHICAL ENTRIES are entered by the father's surname, followed by the mother's maiden name. Many Mexicans, however, do not use their mother's maiden name, or do so inconsistently, thus making it confusing to identify an individual's career. When the mother's maiden name appears in parentheses, it indicates that the individual typically uses only his father's name. The date of death, if known, appears below the individual's name in the biography. If the date is not known, the word deceased appears. Several individuals, at the time of publication, may still be alive. In such cases, of course, no information appears to the right of the name.

The biographical information in the entries is divided into twelve categories, to correspond with the early volumes. When information for any category is unavailable, the word unknown is entered. The word none indicates that the category did not apply to the individual biographee, such as no union activities or military service. When a position is italicized in a biography, it means that the position is also listed in the appendixes. When a person's name is italicized in the biography, that individual has his or her own biographical entry. A name italicized in the appendix means that a biography of that individual appears in this book.

The appendixes can be used to reconstruct the leadership of a given agency over time. These appendixes make it possible to examine governmental positions without knowing the names of the officeholders. Also, for hundreds of important and lesser figures, whose biographies do not appear in this volume, a skeletal career of one's positions, that is to say, a political outline of an individual, can be sketched by examining positions held. This can be particularly useful for numerous minor figures about whom biographical information would be difficult, if not impossible, to locate.

The categories are:

A] Date of birth.

B] Birthplace, city and state, sometimes including the municipality if the city is a small village, mining community, or farm.

c] Education: primary, secondary, preparatory, professional, and college education with the dates of attendance and graduation, if possible. Most 
individuals who attended college went to regional institutions, or professional schools in Mexico City which became the National University of Mexico (later the National Autonomous University of Mexico-UNAM) in 1910. The schools which form the antecedent of the National University are the School of Mines (later the National School of Engineering), the National School of Medicine, and the National School of Law, all located in Mexico City. I have added the word National to the names of these schools to indicate they are the antecedents of those schools. The military college, which many of the military-political figures attended, is referred to in the biographies as the National Military College, the antecedent of the Heroic Military College. In the nineteenth century, many individuals were certified as lawyers by the courts, and not by the schools themselves. When those institutions and the date of certification are known, they are included in the biography. The entry "no degree" indicates that the individual never completed professional or university studies. Teaching and administrative positions at any level of education are also included in this category.

D] Elective positions: any positions which at least nominally are attained through the electoral process, from council member to president. Provisional, interim, and substitute governors are not included in this category, but under the appointive governmental positions category. During the Porfiriato, 1884-1911, some individuals were elected simultaneously to more than one position as federal deputies; thus duplicate dates and different states and districts are not errors. The individual could serve in only one post, and his alternate was required to take the alternate post.

E] Party positions: any known affiliations to a political party or campaign are included. Candidates for office are also included.

F] Appointive governmental positions: any appointive office at the local, state, national, and international levels. I have attempted, if possible, to list these in chronological order, to give a clearer notion of the individual's career. Many individuals hold multiple appointive posts, or appointive posts simultaneously with elective offices, and duplicate dates are not in error.

G] Group activities, including intellectual, student, labor, and other organizations. Only selected, numbered members in cultural or professional academies are noted.

H] Nongovernmental positions: excluding education and the military, these include professional jobs, self-employment, ownership of land and firms, and, generally, any post in the private sector. Also, if the individual is a significant author, poet, or artist, that information will appear in this entry.

I] Grandparents, parents, spouses, siblings, friends: relevant family data, including father's occupation, as well as information about relatives and friends who have held important governmental positions. Particular care has been taken to try to identify other relatives who have held prominent political offices, or who are married to such individuals. The occupation of the parent is the r uost difficult variable about which to obtain information. I 
have used extensive genealogical sources to provide more information about family background. Political mentors are also identified.

J] Military experience: detailed career information, if available, including date and rank of entry into service, date of rank, highest rank reached, important battles, if known, and faction supported during periods of rebellion. Many of the entries are based on Secretariat of War data. Guerrilla and revolutionary activities also are included.

к] Miscellaneous information: unusual information about an individual's career, including imprisonment, exile, cause of death, if not natural, duels, or some notable feat.

L] Addition sources: books, reference works, government directories, newspapers, magazines, educational files. Biographical monographs about an individual are not cited, since they can be easily found in the card catalog. The word letter indicates that some of the information was confirmed by a relative or by correspondence from another source or agency. 
THIS PAGE INTENTIONALLY LEFT BLANK 